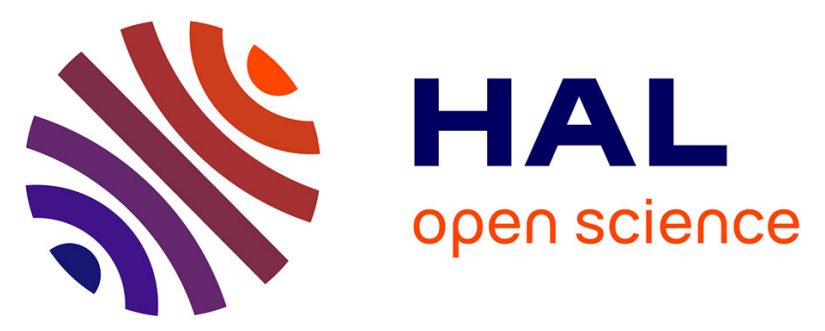

\title{
Microcellular Foaming of Polymethylmethacrylate in a Batch Supercritical CO2 Process: Effect of Microstructure on Compression Behavior
}

\author{
Jose Antonio Reglero Ruiz, Philippe Viot, Michel Dumon
}

\section{- To cite this version:}

Jose Antonio Reglero Ruiz, Philippe Viot, Michel Dumon. Microcellular Foaming of Polymethylmethacrylate in a Batch Supercritical CO2 Process: Effect of Microstructure on Compression Behavior. Journal of Applied Polymer Science, 2010, 118 (1), pp.320-331. hal-01006872

\section{HAL Id: hal-01006872 \\ https://hal.science/hal-01006872}

Submitted on 16 Jun 2014

HAL is a multi-disciplinary open access archive for the deposit and dissemination of scientific research documents, whether they are published or not. The documents may come from teaching and research institutions in France or abroad, or from public or private research centers.
L'archive ouverte pluridisciplinaire HAL, est destinée au dépôt et à la diffusion de documents scientifiques de niveau recherche, publiés ou non, émanant des établissements d'enseignement et de recherche français ou étrangers, des laboratoires publics ou privés. 


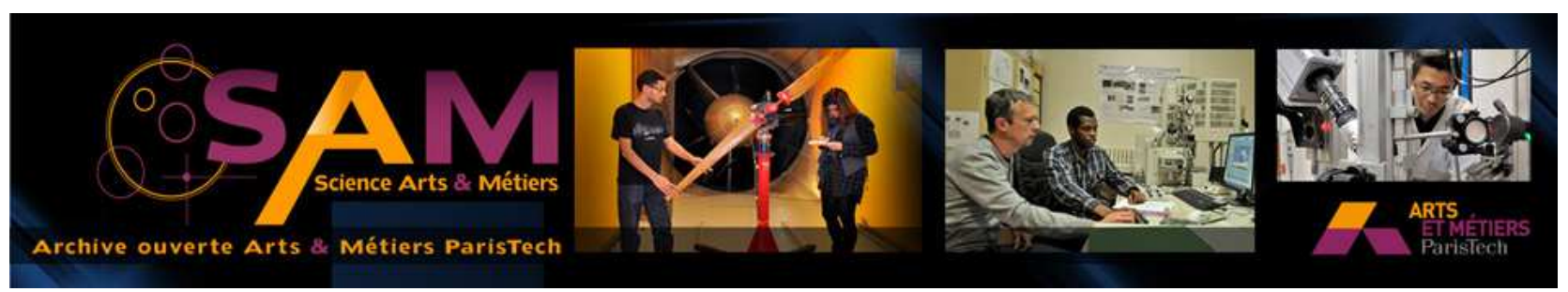

\section{Science Arts \& Métiers (SAM)}

is an open access repository that collects the work of Arts et Métiers ParisTech researchers and makes it freely available over the web where possible.

This is an author-deposited version published in: http://sam.ensam.eu

Handle ID: .http://hdl.handle.net/10985/8262

\section{To cite this version :}

Jose Antonio REGLERO RUIZ, Philippe VIOT, Michel DUMON - Microcellular Foaming of Polymethylmethacrylate in a Batch Supercritical CO2 Process: Effect of Microstructure on Compression Behavior - Journal of Applied Polymer Science - Vol. 118, n¹, p.320-331 - 2010 


\title{
Microcellular Foaming of Polymethylmethacrylate in a Batch Supercritical $\mathrm{CO}_{2}$ Process: Effect of Microstructure on Compression Behavior
}

\author{
Jose Antonio Reglero Ruiz, ${ }^{1}$ Philippe Viot, ${ }^{2}$ Michel Dumon ${ }^{1}$ \\ ${ }^{1}$ Laboratoire de Chimie de Polymères Organiques (LCPO), Université Bordeaux 1, IPB. 16 Avenue Pey-Berland, \\ Pessac, Cedex 33607, France \\ ${ }^{2}$ Laboratoire Matériaux Endommagement Fiabilité (LAMEFIP), ENSAM, Esplanade de Art et Métiers, Talence, \\ Cedex 33405, France
}

\begin{abstract}
Microcellular foaming of reinforced core/ shell Polymethylmethacrylate (PMMA) was carried out by means of supercritical $\mathrm{CO}_{2}$ in a single-step process. Samples were produced using a technique based on the saturation of the polymer under high pressure of $\mathrm{CO}_{2}$ (300 bars, $40^{\circ} \mathrm{C}$ ), and cellular structure was controlled by varying the depressurization rate from $0.5 \mathrm{bar} / \mathrm{s}$ to $1.6 \times 10^{-2} \mathrm{bar} / \mathrm{s}$ leading to cell sizes from $1 \mu \mathrm{m}$ to $200 \mu \mathrm{m}$, and densities from 0.8 to $1.0 \mathrm{~g} / \mathrm{cm}^{3}$. It was found that the key parameter to control cell size was depressurization rate, and larger depressurization rates generated bigger cell sizes. On the other hand, variation of the density of the samples was not so considerable. Low rate compression tests were carried out, analyzing the dependence of mechanical parame-
\end{abstract}

ters such as elastic modulus, yield stress and densification strain with cell size. Moreover, the calculation of the energy absorbed for each sample is presented, showing an optimum of energy absorption up to $50 \%$ of deformation in the micrometer cellular range (here at a cell size of about $5 \mu \mathrm{m}$ ). To conclude, a brief comparison between neat PMMA and the core/shell reinforced PMMA has been carried out, analyzing the effect of the core/shell particles in the foaming behavior and mechanical properties. () 2010 Wiley Periodicals, Inc. J Appl Polym Sci 118: 320-331, 2010

Key words: microcellular foam; PMMA; supercritical CO2; compression properties

\section{INTRODUCTION}

In the last years, the use of supercritical carbon dioxide $\left(\mathrm{scCO}_{2}\right)$ as a medium for polymer synthesis and for polymer processing has increased greatly. ${ }^{1}$ The unique properties associated with supercritical fluids, and especially with supercritical $\mathrm{CO}_{2}$, because of its chemical, environmental, and economical advantages have been explored in fields such as organic synthesis, catalysis, and materials science. ${ }^{2,3}$ In this work, the use of supercritical carbon dioxide as a physical foaming agent for a non-reactive processing is investigated. In this direction, microcellular polymers can be obtained through the gas foaming technique, by the employ of supercritical carbon dioxide.

Microcellular foams are defined as having average cell sizes in the range of 1-10 $\mu \mathrm{m}$, and cell densities on the order of $10^{9}-10^{15}$ cells $/ \mathrm{cm}^{3}$. Such structures were proposed by Suh and coworkers ${ }^{4,5}$ and it is well known that inert gasses, such as $\mathrm{CO}_{2}$ can be

Correspondence to: J. A. R. Ruiz (reglero-ruiz@enscpb.fr). Contract grant sponsor: ANR (Agence Nationale de la Recherche); contract grant number: ANR-07-BLAN-0184. used to foam amorphous polymeric materials. The low critical conditions of $\mathrm{scCO}_{2}\left(31.1^{\circ} \mathrm{C}\right.$ and $\left.73.8 \mathrm{bar}\right)$ offers many advantageous properties, like a tuneable solvent power, plasticization of glassy polymers and higher diffusion rates. ${ }^{6,7}$ To produce the microcellular structure, there are two main batch processes.

In the first process, denominated single-step process, the polymer is saturated with $\mathrm{CO}_{2}$ in the supercritical regime, during a fixed time. After saturation, the sample, approaching or being in a rubbery state, is depressurized to atmospheric pressure, taking advantage of the swelling and plasticization of the polymer, which reduces the glass transition temperature, allowing the gas expansion. In this method, microstructure may be controlled by changing the saturation temperature and depressurization rates. Following this line of investigation, several microcellular polymers have been already obtained, including polystyrene, ${ }^{6,8}$ polycarbonate, ${ }^{9}$ polystyrene-co-methylmethacrylate, ${ }^{10}$ and Polymethylmethacrylate. $^{11,12}$

In the second process, a two-step process, the polymer is saturated with $\mathrm{scCO}_{2}$ at high pressure and low temperature, in a glassy state. Next, the polymer/gas mixture is quenched into a supersaturated state by reducing drastically the pressure. Finally, after removing rapidly the sample from the 
$\mathrm{CO}_{2}$ vessel, polymer is foamed by heating to a temperature above the glass transition temperature (e.g. in a hot bath), leading to nucleation and cell growth. Foaming temperature and foaming time are the key parameters to adjust the cellular structure of the final product. ${ }^{13,14}$ Using this process, microcellular polymers, such as polystyrene, ${ }^{15}$ polypropylene, ${ }^{16,17}$ polyethersulfone and polyphenylsulfone, ${ }^{18,19}$ polycarbonate, ${ }^{20}$ Poly (methyl methacrylate ${ }^{21}$ and biodegradable poly (lactic acid) have been prepared. ${ }^{22}$

In all the cases, one of the main objectives is reducing material bulk density, reducing cell size and/or increasing the cell number density of the cellular polymer produced. For this reason, solubility of polymers and copolymers in supercritical $\mathrm{CO}_{2}$ has been widely investigated, ${ }^{23}$ as well as the use of nanoclays and nanocharges as nucleating agents for bubble creation. ${ }^{24-26}$ In this second case, carbon nanotubes and nanosilica components have been demonstrated as good nucleating agents, although its use is limited due to economical reasons and the problems derived from the manipulation of the products.

Regarding the solubility of polymers in supercritical $\mathrm{CO}_{2}$, it is well known that acrylate/methacrylate, siloxane and fluorinated polymers present high affinity to $\mathrm{ScCO}_{2} \cdot{ }^{27,28}$ However, the fluorinated polymers are not commodity polymers, and only laboratory research involving thin film porous samples have been carried out. ${ }^{29}$ On the other hand, PMMA is a commercially available polymer, and its use is much more extended than fluorinated polymers. As detailed before, several works have been presented studying the microcellular processing of this polymer, although there is a lack of investigation in mechanical properties under compression tests. In this work, we present the compression properties of a collection of microcellular PMMA materials produced in a single-step batch process, showing the effect of decompression rates in the final microcellular structure and in the most important mechanical parameters. The first part of the study has the objective to elaborate porous or cellular PMMA over the largest accessible micron cell-size range in a one step process in bulk samples, and to correlate microstructure to compression behavior.

\section{EXPERIMENTAL}

\section{Materials}

Poly methyl methacrylate (PMMA, DRT 101) was kindly supplied by Altuglas Company-Arkema, (France) in the form of pellets. This polymer is designed for high impact resistance and it is modified with core/shell rubber particles of diameter 250 $\mathrm{nm}$ as it is showed in Figure 1. Experimental details
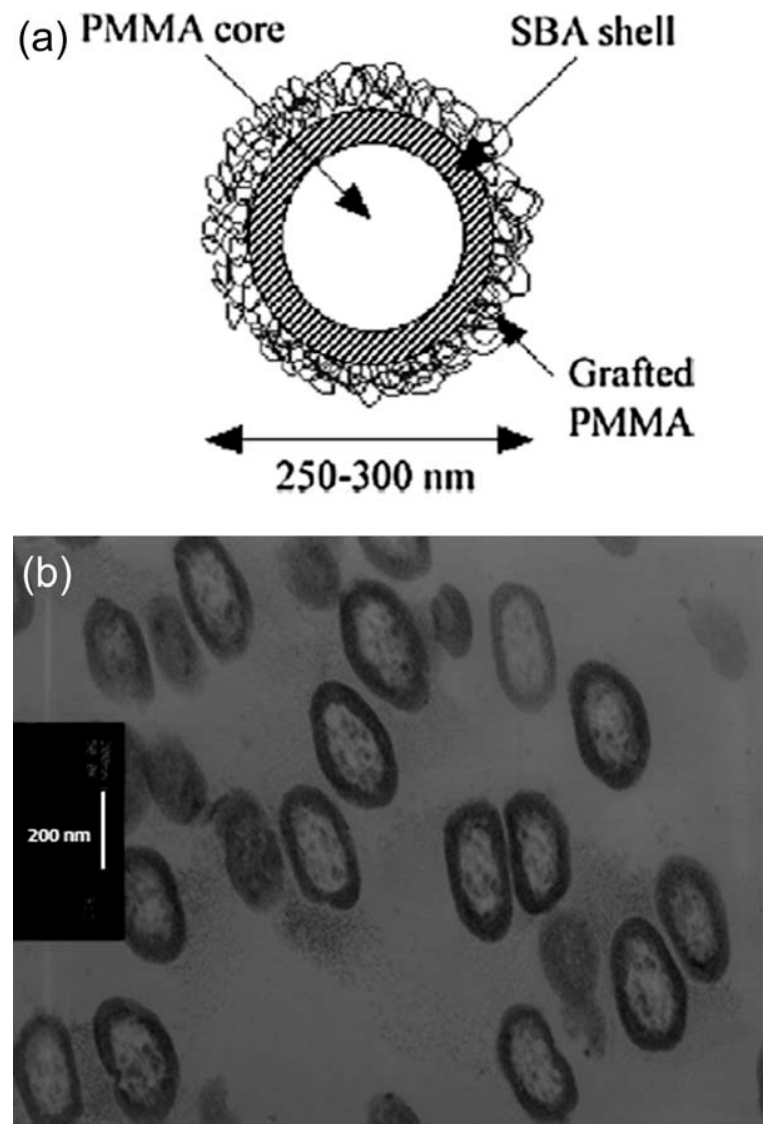

Figure 1 (a) Scheme of the base core/shell rubber particle geometry. (b) TEM image of thin films of high impact PMMA.

about blending and production of this polymer can be found elsewhere. ${ }^{30}$

The role of these particles is to improve the impact resistance without decreasing the glass transition temperature and without significantly compromising the optical properties (mainly transparency should be maintained, especially when the refraction index of both phases is matched thanks to the PMMA corona grafted around the SBA shell).

As explained before, non-reinforced neat PMMA resin (Reference V825 from Arkema) was also used to evaluate the effect of the core/shell particles in the foaming behavior and compression properties.

Glass transition temperature was obtained by means of differential scanning microscopy (DSC), in a two cycles process, from $-50^{\circ} \mathrm{C}$ to $200^{\circ} \mathrm{C}$ at a velocity of $10^{\circ} \mathrm{C} / \mathrm{min}$. In addition, Gel permeation chromatography (GPC) technique was employed to determine the average molar mass, using Tetrahydrofuran (THF) as a solvent (concentration of $3 \mathrm{mg} /$ $\mathrm{mL}$ ), with a wavelength of $254 \mathrm{~nm}$.

A value of $T_{g}$ of $381 \mathrm{~K}$ was found, whereas GPC shows a peak observed at a retention time between 15 and $20 \mathrm{~min}$, resulting an average molar mass $M_{n}$ of $60,000 \mathrm{~g} / \mathrm{mol}$. Moreover, a value of bulk density 
$\rho_{\mathrm{s}}$ of $1.19 \mathrm{~g} / \mathrm{cm}^{3}$ was used for further calculations. On the other hand, carbon dioxide $(99.9 \%)$ was obtained from Air Liquide (France).

Pellets received were injected-molded into dogbones $\left(50 \times 15 \mathrm{~mm}^{2}\right)$ with $3 \mathrm{~mm}$ thickness, using a small scale injection molding machine developed by DSM Xplore. The working temperature was fixed at $250^{\circ} \mathrm{C}$, whereas mold temperature was $60^{\circ} \mathrm{C}$. The injection pressure was fixed at 12 bar. The samples obtained showed a good transparency and a good surface appearance.

\section{Microcellular foamings}

Microcellular foaming experiments were carried out in a high pressure reactor provided by TOP Industry (France), with a capacity of $300 \mathrm{~cm}^{3}$ and capable of operating at maximum temperature of $250^{\circ} \mathrm{C}$ and 400 bar. The reactor is equipped with an accurate pressure pump controller provided by Teledyne ISCO, and controlled automatically to keep the temperature and pressure at the desired values.

As stated before, foaming experiments were performed in a single-step batch process. First, samples were saturated with supercritical $\mathrm{CO}_{2}$ at $40^{\circ} \mathrm{C}$ at a maintained pressure of 300 bar during $24 \mathrm{~h}$. Saturation time was selected to assure the complete equilibrium swelling of the polymer by $\mathrm{CO}_{2}{ }^{20,23,31}$ The depression of the glass transition temperature induced by supercritical $\mathrm{CO}_{2}$ in several amorphous polymers is well known, ${ }^{8,25}$ showing a linear relation $T_{g}$-pressure, but in PMMA, a retrograde behavior is exhibited. ${ }^{32-34}$ The $T_{g}$-Pressure curve is no longer linear and presents a "retrograde envelope" between 2 and $6 \mathrm{MPa}$, i.e. two transitions are detected under a constant pressure. If saturation pressure is set at 3.9 $\mathrm{MPa}$, these two transitions are located around $10^{\circ} \mathrm{C}$ and $80^{\circ} \mathrm{C}$ but at much higher pressures (such as those used in our study, $30 \mathrm{MPa}$ ), both saturation and foaming are occurring out of the "retrograde envelope." A foaming temperature of $40^{\circ} \mathrm{C}$ was chosen to perform the experiments, with two main objectives. First, foaming at temperatures close to $T_{g}$ of the plasticized polymer assures the growing of cells during the gas expansion, and second, gas solubility increases at lower temperatures, which means that the quantity of gas absorbed for the sample is higher, and more nucleation sites are formed.

In a first row of experiments, samples $(50 \times 15 \times$ $3 \mathrm{~mm}^{3}$, mass $\approx 3.2 \mathrm{~g}$ ) were removed periodically from the reactor and weighted on a precision balance of accuracy $10 \mu \mathrm{g}$ to know the quantity of gas absorbed during the whole process. After the equilibrium amount of gas had been absorbed by the samples, microcellular foaming was produced releasing the pressure in different time laps, from $60 \mathrm{~s}$ to $30 \mathrm{~min}$ corresponding to rates of $0.5 \mathrm{MPa} / \mathrm{s}$ to
$1.6 \times 10^{-2} \mathrm{MPa} / \mathrm{s}$. Low rates between $0.1 \mathrm{MPa} / \mathrm{s}$ and $1.6 \times 10^{-2} \mathrm{MPa} / \mathrm{s}$ allowed to keep temperature constant inside the reactor, however, the fastest depressurization rates makes it impossible to maintain temperature and, for example, temperature drops down to $-10^{\circ} \mathrm{C}$ were noticed at the end of the foaming process. After foaming, samples were removed from the reactor, and the original transparent sheets became opaque and white, presenting smooth surfaces.

\section{Characterization}

Foam density $\rho_{f}$ was determined by water-displacement method, based on Archimedes principle. Densities were calculated by measuring the volume of water displaced by the sample divided into the sample mass. It is important to notice that because of the closed cell structure of the foam samples, there was no uptake of water by the samples during measurements. Moreover, relative foam density, the ratio of the density of the foam and the density of the solid polymer was calculated. At least three measurements were carried out for each sample produced.

Cellular structure was analyzed by means of scanning electron microscopy (model HITACHI S$3000 \mathrm{~N})$. For the preparation of the samples, foams were frozen in liquid nitrogen and fractured to assure that the microstructure remained intact. For the observations, surfaces were coated with gold using a sputter coater (model EMSCOPE SC 500), in argon atmosphere. The micrographs obtained were analyzed to estimate cell size $\varphi$, obtained from direct observation, using a minimum of 100 cells in each calculation, whereas cell density $N_{C}\left(\right.$ cells $\left./ \mathrm{cm}^{3}\right)$ was calculated from the next equation, using the method proposed by Kumar and Suh ${ }^{35}$ :

$$
N_{C} \cong\left(\frac{n M^{2}}{A}\right)^{3 / 2}
$$

where $n$ is the number of cells observed in a SEM micrograph, $\mathrm{A}$ is the area of the micrograph in $\mathrm{cm}^{2}$ and $\mathrm{M}$ is the magnification factor.

To perform compression tests, cylindrical samples of $9 \mathrm{~mm}$ diameter were machined from the foamed sheets. The thickness of the samples varied with foam density and ranged between 3.5 and $5 \mathrm{~mm}$. All the compression tests were carried out at room temperature using a universal test machine (Zwick, model Z250) with a load cell of $10 \mathrm{KN}$ at a constant crosshead velocity of $0.5 \mathrm{~mm} / \mathrm{min}$. Strain rate varied between $1.6 \times 10^{-3} \mathrm{~s}^{-1}$ and $2.3 \times 10^{-3} \mathrm{~s}^{-1}$. At least, three samples of each batch were tested reporting the average data in this work. Raw data obtained was force $F$ and displacement $\Delta l$, selecting the test 
parameters to assure at least the $60 \%$ of total deformation of the sample in each test. Main mechanical parameters, such as elastic modulus, yield stress, densification strain, and density of energy absorbed were determined.

\section{RESULTS AND DISCUSSION}

\section{Absorption of $\mathrm{CO}_{2}$ into reinforced core/shell PMMA}

The absorption kinetics of $\mathrm{CO}_{2}$ in reinforced core/ shell PMMA at the given conditions $\left(300 \mathrm{bar}, 40^{\circ} \mathrm{C}\right)$ was measured experimentally. It is well known that the mass uptake of gasses into polymers, at a given time, is described as follows ${ }^{16}$ :

$$
M_{t} / M_{\infty}=4(D / \pi)^{0.5}\left(t^{0.5} / L\right)
$$

where $M_{t} / M_{\infty}$ is the relation of the total amount of gas that has diffused into the polymer at a time $t$ divided by the total amount of gas diffused at a infinite time, $D$ represents the diffusivity of the gas into the polymer, measured in $\mathrm{cm}^{2} / \mathrm{s}$, and finally $L$ represents the total thickness of the sample. A simple representation of $M_{t}$ as a function of $\left(t^{0.5} / L\right)$ can be fitted to a straight line of slope $4(D / \pi)^{0.5}$. Experimental data was obtained removing the samples and immediately transferred to a high precision balance to record the increased percentage of weight due to gas absorption. In Figure 2 is presented the absorption curve of $\mathrm{CO}_{2}$ into the particular reinforced PMMA used:

From the data of the Figure 2, a diffusivity value of $D \approx 3.123 \times 10^{-6} \mathrm{~cm}^{2} / \mathrm{s}$ was calculated, which is in agreement with data offered in bibliography. ${ }^{36}$ However, it is important to notice that this onedimensional diffusion is calculated assuming that thickness is much more smaller that other dimen-

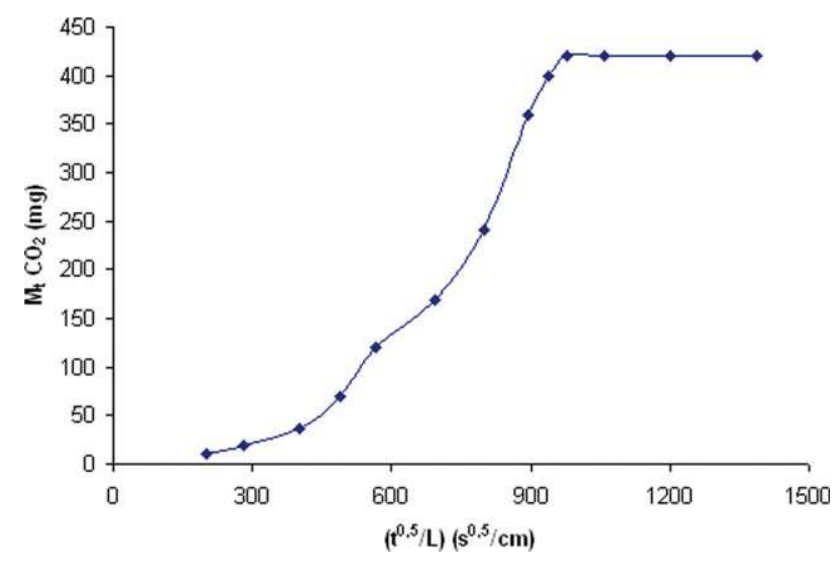

Figure 2 Absorption of CO2 into PMMA at $300 \mathrm{~b}$ and $40^{\circ} \mathrm{C}$. [Color figure can be viewed in the online issue, which is available at www.interscience.wiley.com.]

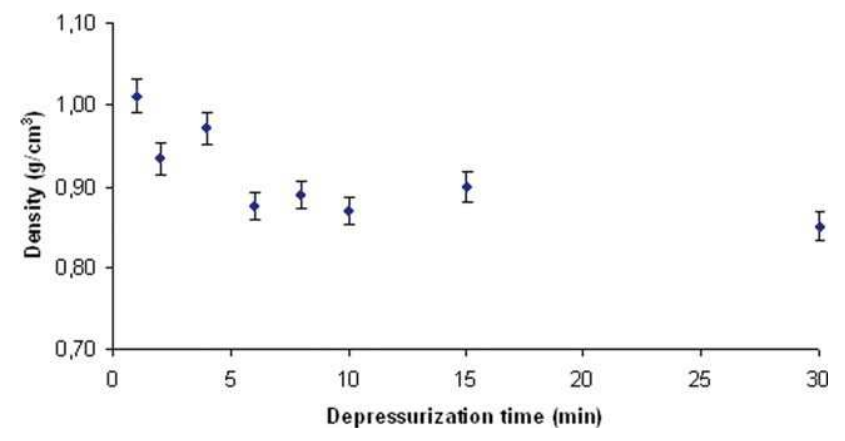

Figure 3 Reinforced PMMA foam density as a function of depressurization time. (Foaming conditions $300 \mathrm{~b}$ and $40^{\circ} \mathrm{C}$ ). [Color figure can be viewed in the online issue, which is available at www.interscience.wiley.com.]

sions, and must be considered as an estimation, as D is a function of gas concentration and it changes during the experiment. Moreover, to assure the maximum quantity of gas absorbed in the reinforced PMMA, the saturation time was selected to $24 \mathrm{~h}$, which leads to percentages of $12 \%$ of $\mathrm{CO}_{2}$ absorbed in the sample (420 $\mathrm{mg}$ of gas absorbed considering $3.2 \mathrm{~g}$ of each unfoamed sample, approximately). This $\mathrm{CO}_{2}$ uptake is representative of a classical high molar mass PMMA although the considered PMMA is an impact modified polymer with a neat $T_{g}=381$ $\mathrm{K}$. Under 300 bars at $40^{\circ} \mathrm{C}, T_{g}$ can be evaluated at $25^{\circ} \mathrm{C}$ approximately, ${ }^{32}$ in Figure 2 at the same quantity of $\mathrm{CO}_{2}$ and the polymer can be considered in a rubbery state when nuclei are formed at the beginning of cell growth. Then the temperature drop depends on the depressurization rate so that the polymer may or not become glassy, freezing the foaming process (growth and coalescence).

Finally, it can be added that thickness is the key parameter for selecting saturation time, and samples with lower thickness can be used to reduce the saturation time. On the other hand, the thickness of the foamed samples must be enough to perform mechanical test, assuring that a representative number of cells are compressed during the process.

Moreover, saturation pressure is directly related to the amount of $\mathrm{CO}_{2}$ absorbed into the polymer. As saturation pressure increases, small cell sizes are obtained. Additionally, the homogeneous nucleation theory predicts an increase of cell density, more nuclei are produced, as saturation pressure increases. ${ }^{37}$ For this reason, in all our experiments saturation pressure was fixed at 300 bars.

\section{Density}

The density results are presented in Figure 3, as a function of depressurization time, for the reinforced core/shell PMMA foams. It can be seen that density decreases with depressurization time, from $1.00 \mathrm{~g} /$ 
$\mathrm{cm}^{3}$ corresponding to $1 \mathrm{~min}$ of depressurization time $(0.5 \mathrm{MPa} / \mathrm{s})$, to a minimum value of $0.85 \mathrm{~g} / \mathrm{cm}^{3}$ related to $30 \mathrm{~min}$ of depressurization time $(1.6 \times$ $\left.10^{-2} \mathrm{MPa} / \mathrm{s}\right)$. As mentioned before, although the foaming experiments were not carried out at the same temperature, no great variation of density is found. On the other hand, this result is in accordance with the small variation in density described in the preparation of microcellular foams from amorphous high- $T_{g}$ polymers, such as polysulfone foams ${ }^{18,21}$ or polystyrene, ${ }^{8}$ where maximum variations of $20 \%$ (with respect to density of unfoamed polymers) are described as a function of foaming time. When density is close to 1 two limiting factors are present: (i) growth is limited by the proximity of the glassy state due to fast cooling, (ii) the transformation of $\mathrm{scCO}_{2}$ into liquid $\mathrm{CO}_{2}$, which is not a foaming agent. These reasons are similar to the case of foaming near the "retrograde envelope," $0^{\circ} \mathrm{C}$ and $3 \mathrm{MPa}^{34}$

\section{Cellular structure}

Reinforced core/shell PMMA

Several SEM micrographs showing the cellular structure of the foams produced are presented in Figure 4. As it is seen in the figure, cell size is lower at minimum depressurization time-i.e., maximum rate[1 $\mu \mathrm{m}$, Fig. 4(a)], whereas increasing depressurization times-i.e., minimum rate-lead to greater cell sizes and less homogeneous pores, [150-200 $\mu \mathrm{m}$, Fig. $4(\mathrm{~d})$ ]. It is clear that increasing depressurization times allows nucleated cells more time to develop. However, from Figure 4(d) it is clear that large cells not retain spherical geometry, and homogeneity is much lower that observed in foams with small cell sizes. It is important to remark that for the density to maintain constant as cell size increases, as showed in Figure 3, the cell density decreases, and coalescence occurs at larger depressurization times. As expected, all the structures obtained are closed-cell.
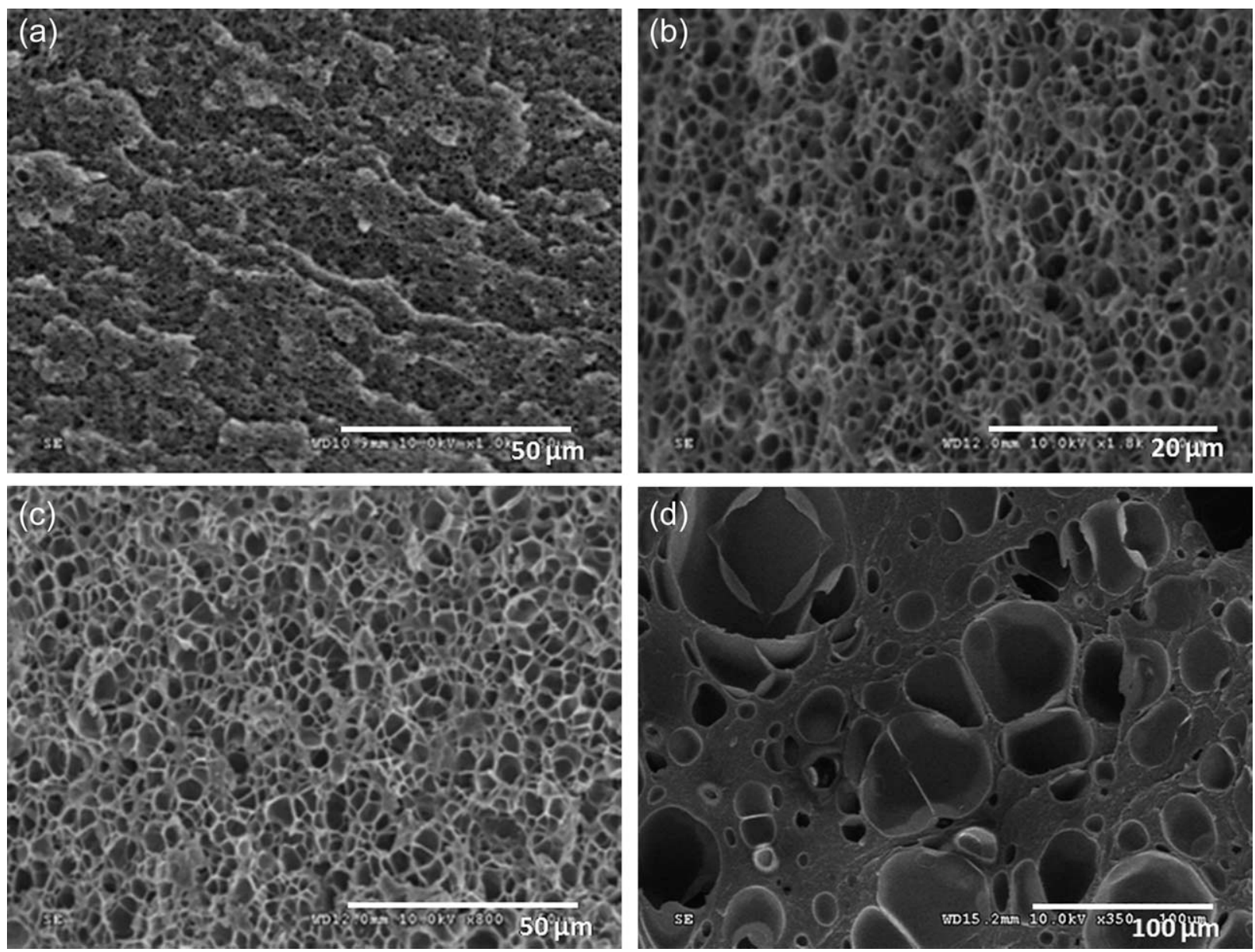

Figure 4 (a) SEM micrograph of the reinforced PMMA foams produced at 1 min of depressurization time. (b) SEM micrograph of the reinforced PMMA foams produced at 2 min of depressurization time. (c) SEM micrograph of the reinforced PMMA foams produced at $6 \mathrm{~min}$ of depressurization time. (d) SEM micrograph of the reinforced PMMA foams produced at $30 \mathrm{~min}$ of depressurization time. 


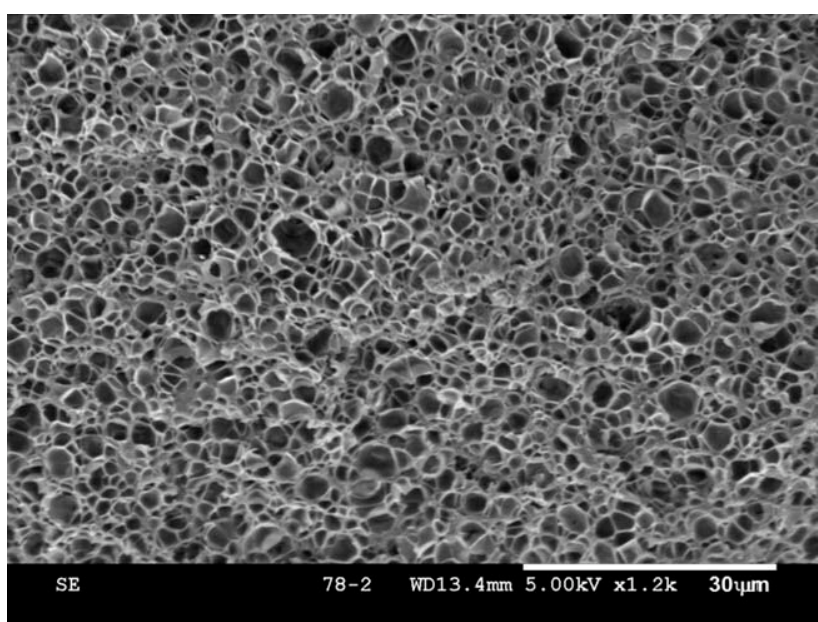

Figure 5 SEM micrograph of the neat PMMA foam produced at $2 \mathrm{~min}$ of depressurization time.

\section{Neat PMMA resin}

In the case of neat PMMA, foaming experiments were carried out in the same experimental conditions, and cellular structure were analyzed by means of SEM observations. As an example, Figure 5 presents a SEM micrograph of a neat PMMA sample fabricated at $2 \mathrm{~min}$ of depressurization rate. As it can be seen, no great differences in cellular structure and average cell size between neat PMMA and reinforced core/shell PMMA are obtained [see Fig. 4(b)], which indicates that the core/shell particles do not play an important role as nucleating agents. Similar results were observed for all the samples produced, with similar density values compared to reinforced core/shell PMMA material.

In Table I presents the data derived from SEM observations in reinforced core/shell PMMA and neat PMMA, together with the cell density values calculated from eq. (1). We include here the foam density values obtained for both polymers. It can be seen that cell density decreases slightly with depressurization time in both samples. As depressurization times increases, coalescence appears and this effect decreases. As seen in the SEM micrographs, micro- structural parameters (average cell size $\varphi$, foam density $\rho$, and cell density $N_{C}$ ) show no remarkable differences between reinforced core/shell PMMA and neat PMMA foams. In addition, it is important to remark that sorption of $\mathrm{CO}_{2}$ in neat PMMA presented a similar behavior than reinforced core/shell PMMA, which is in agreement with the results presented in Table I.

\section{Compression tests}

\section{Reinforced core/shell PMMA}

Stress-Strain curves obtained for the samples produced are presented in Figure 6. Results are divided in three different groups. In Figure 6(a) results of samples obtained from $1 \mathrm{~min}$ and $2 \mathrm{~min}$ of depressurization rate time are presented, together with the stress-strain curve of the unfoamed PMMA. In Figure $6(\mathrm{~b})$ are showed the results of microcellular materials obtained using 4, 6 and 8 min respectively. Finally, in Figure 6c) are illustrated the results of microcellular PMMA samples produced using 10, 15 , and $30 \mathrm{~min}$. In the three graphs, the stress scale employed is the same, to assure a good comparison between all the results.

From the previous graphs, it is clear that increasing depressurization time is reflected in the stressstrain curve appearance. First, the behavior of microcellular foams produced using $1 \mathrm{~min}$ of depressurization rate is rather similar to unfoamed sample [Fig. 6(a)]. It can be explained from the SEM micrographs presented previously [Fig. 4(a)], in which the cellular structure produced assembles to a continuous solid material with small isolated pores. Increasing depressurization time allows the coalescence and expansion of the gas inside the nucleated cells, and stress-strain curves show the typical behavior of a cellular material.

In a first approximation, ${ }^{38}$ Gibson divides the stress-strain curve of a cellular material under compression in three different zones. First, the initial linear zone, between initial point and a strain value $\varepsilon_{1}$,

TABLE I

Structural Parameters of the Samples Produced

\begin{tabular}{|c|c|c|c|c|c|c|}
\hline \multirow[b]{2}{*}{$D_{\text {rate }}(\min )$} & \multicolumn{3}{|c|}{ Neat PMMA } & \multicolumn{3}{|c|}{ Reinforced core/shell PMMA } \\
\hline & $\varphi(\mu \mathrm{m})$ & $\rho\left(\mathrm{g} / \mathrm{cm}^{3}\right)$ & $N_{C}\left(\right.$ cells $\left./ \mathrm{cm}^{3}\right)$ & $\varphi(\mu \mathrm{m})$ & $\rho\left(\mathrm{g} / \mathrm{cm}^{3}\right)$ & $N_{C}\left(\right.$ cells $\left./ \mathrm{cm}^{3}\right)$ \\
\hline 1 & 1 & 1.00 & $1.56 \times 10^{14}$ & 1 & 1.01 & $2.59 \times 10^{14}$ \\
\hline 2 & 4 & 0.98 & $1.13 \times 10^{13}$ & 3 & 0.93 & $1.42 \times 10^{13}$ \\
\hline 4 & 7 & 0.95 & $2.23 \times 10^{12}$ & 5 & 0.97 & $2.58 \times 10^{12}$ \\
\hline 6 & 12 & 0.86 & $1.5 \times 10^{12}$ & 7 & 0.88 & $1.39 \times 10^{12}$ \\
\hline 8 & 15 & 0.89 & $4.13 \times 10^{11}$ & 10 & 0.89 & $4.57 \times 10^{11}$ \\
\hline 10 & 45 & 0.86 & $1.83 \times 10^{10}$ & 30 & 0.87 & $1.80 \times 10^{10}$ \\
\hline 15 & 65 & 0.83 & $3.43 \times 10^{9}$ & 50 & 0.90 & $3.50 \times 10^{9}$ \\
\hline 30 & 230 & 0.81 & $5.98 \times 10^{8}$ & 200 & 0.85 & $6.50 \times 10^{8}$ \\
\hline
\end{tabular}



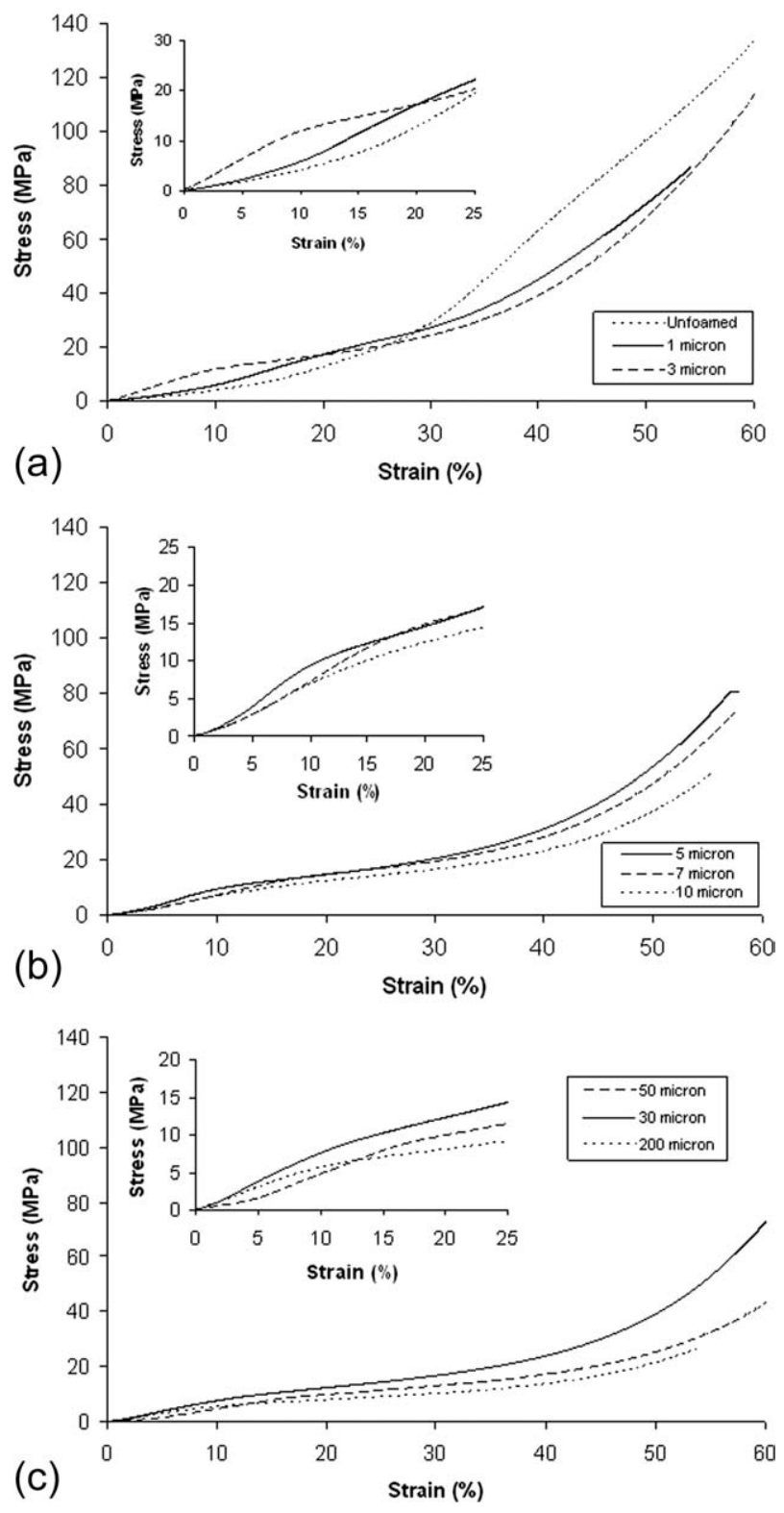

Figure 6 (a) Stress-Strain curves obtained in the compression mechanical tests for unfoamed sample and microcellular reinforced PMMA foams with cell sizes of $1 \infty \mathrm{m}$ and $3 \infty \mathrm{m}$. (b) Stress-Strain curves obtained in the compression mechanical tests for microcellular reinforced PMMA foams with cell sizes of $5 \infty \mathrm{m}, 7 \infty \mathrm{m}$, and $10 \infty$ $\mathrm{m}$. (c) Stress-Strain curves obtained in the compression mechanical tests for microcellular reinforced PMMA foams with cell sizes of $30 \propto \mathrm{m}, 50 \propto \mathrm{ml}$, and $200 \propto \mathrm{m}$.

where the relation stress-strain is linear, and its slope corresponds to the foam compressive elastic modulus E. Second, the plateau regime, between $\varepsilon_{1}$ and strain value $\varepsilon_{2}$ in which deformation occurs at a constant stress, namely yield stress of the material $\sigma_{y}$. Finally, the densification zone, from $\varepsilon_{2}$ to the end of the test, where cells begin to collapse and stress increase greatly.

However, experimental stress-strain curves differ slightly from the model purposed previously. Figure
7 presents an experimental compression test obtained in our work, (sample decompressed during 2 min, cell size $3 \mu \mathrm{m}$ ).

In this figure, several parameters must be defined, as a function of the nominal strain along the test. Different regimes are delimited as follows:

i. Initial phase of the test $\left(\varepsilon<\varepsilon_{\mathrm{a}}\right)$. Corresponds to the first stage of the compression test, before the linear regime.

ii. Linear regime $\left(\varepsilon_{\mathrm{a}}<\varepsilon<\varepsilon_{\mathrm{b}}\right)$. Corresponds to the linear regime of the test. In this regime, the compressive elastic modulus $\mathrm{E}$ is derived from the slope of the linear fitting of the stress-strain curve.

iii. Transition regime between elastic and plastic behavior $\left(\varepsilon_{\mathrm{b}}<\varepsilon<\varepsilon_{\mathrm{c}}\right)$. The upper limit of this regime is defined by the yield stress $\sigma_{y}$.

iv. Plateau regime $\left(\varepsilon_{\mathrm{c}}<\varepsilon<\varepsilon_{\mathrm{d}}\right)$, where the tangent modulus $E_{T}$ is calculated from the slope of the linear fitting of the stress-strain curve. It is important to remark that in the ideal behavior, $E_{T}=0$, and the strain increases with no variation of the stress.

v. Densification regime $\left(\varepsilon<\varepsilon_{\mathrm{d}}\right)$, defined by the collapse of the cell walls and the high increase of the stress until the end of the test.

Regarding theoretical approaches, mechanical behavior of cellular materials can be modeled in different ways. Usually, models are divided into two main categories. First, phenomenological models, which try to fit the experimental data without direct relationship with the physics of the phenomenon. An example of a phenomenological model was stated by Rusch. ${ }^{39-41}$ However, a drawback of the model is its inaccuracy in describing the densification phase when, a consequence of the compression, internal voids progressively disappears. On the other hand, micromechanical models take into account the deformation mechanisms of the cell structure under loading, using several adimensional parameters that reflect these effects. A classical example was stated by Gibson. ${ }^{38}$ Other works deal specifically with the mechanical behavior of PMMA microcellular foams, ${ }^{21}$ but only tensile properties are considered.

The Gibson model divides the compression stress $(\sigma)$-strain $(\varepsilon)$ curve into three main regions:

$$
\begin{gathered}
\sigma=E \varepsilon, \text { if } \varepsilon_{\mathrm{b}}<\varepsilon<\varepsilon_{\mathrm{c}} \\
\sigma=\sigma_{y}, \text { if } \varepsilon_{\mathrm{c}}<\varepsilon<\varepsilon_{\mathrm{d}} \\
\sigma=\sigma_{y} \frac{1}{D}\left(\frac{\varepsilon_{D}}{\varepsilon_{D}-\varepsilon}\right)^{m}, \text { if } \varepsilon>\varepsilon_{\mathrm{d}}
\end{gathered}
$$

where $\sigma$ and $\varepsilon$ are the nominal stress and strain, respectively, considered positive in compression. 


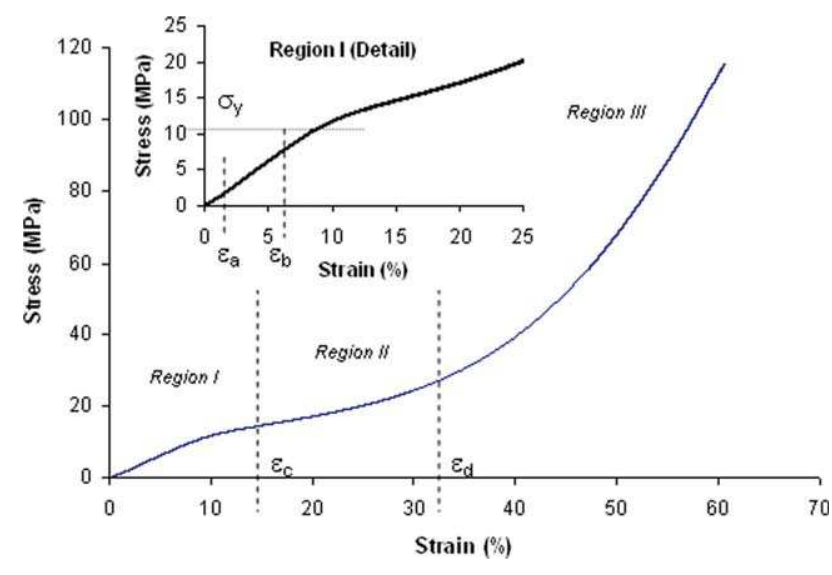

Figure 7 Typical Stress-Strain curves obtained in compression mechanical tests for closed cell cellular materials showing the three main different regimes. [Color figure can be viewed in the online issue, which is available at www.interscience.wiley.com.]

The model has a total number of five parameters to be adjusted. First, E is the positive slope of the elastic part of the curve, derived from a linear fitting of the data, and corresponds to the elastic compressive modulus.

Second, $\sigma_{y}$ is the yield stress, which limits the linear region from the plateau regime. $\varepsilon_{D}$ is a strain value characteristic that limits the beginning of the densification region, being $\varepsilon_{D}$ density dependent. These three parameters are supposed to be densitydependent. Finally, $D$ and $\mathrm{m}$ are dimensionless parameters, both of them density independent. ${ }^{38}$

Experimental data shows, usually, that the plateau stress is not constant during the plastic plateau, as showed previously in Figure 7. This increasing value of the stress during the collapse of the internal cell walls is explained by the cell geometry, the effect of the air inside the cells and by strain hardening behavior of the bulk material. Completely regular cell geometry and a brittle behavior of the base material would show a constant plateau stress.

For this reason, it is usual to modify eq. (4) in the Gibson model, in the next way:

$$
\sigma=\sigma_{y}+E_{T} \varepsilon, \text { if } \varepsilon_{\mathrm{c}}<\varepsilon<\varepsilon_{\mathrm{d}}
$$

where $E_{T}$ is the tangent modulus, density-dependent, added to improve fitting capability.

In our work, we employed this modified Gibson model fitting of the stress-strain curve to obtain a series of characteristics points to describe the behavior of each group of samples. A schematic representation of the approximation employed is showed in Figure 8 , for the microcellular foam obtained using 4 min of depressurization rate.

From this approximation, point $\mathrm{A}$ is obtained from the cross of both linear fittings showed in eqs.
(5) and (8). On the other hand, point B is derived from the intersection of eqs. (7) and 8. Considering an ideal foam behavior, stress at point $\mathrm{A}$ can be considered the yield stress of the material $\sigma_{y}$, and stress at this point determines the beginning of the plateau regime $\left(\varepsilon_{\mathrm{c}}\right)$. Point $\mathrm{B}$ reflects the beginning of the densification and the end of the plateau regime, and the strain value corresponds to $\varepsilon_{D}$. In our case, complete fitting on the 3 regimes is more accurate for samples produced at high depressurizations times, where cells are nucleated and allowed to growth. For samples produced at low depressurization times, linear fitting are less precise and values at points A and B not correspond exactly to that mentioned points. Table II presents the average values of $a, D$ and $m$ parameters obtained in the fittings carried out for all the samples, together with the error range.

Data in the Table II shows the strong dependence of tangent modulus $E_{T}$ with cell size, varying from 0.98 for to 0.24 . In the case of the sample produced at $1 \mathrm{~min}$ of depressurization time, the shape of the curve is similar to that showed for the unfoamed material, and this is reflected in the high value of the parameter $E_{T}(0.98)$. On the other hand, values of $\mathrm{D}$ and $\mathrm{m}$ show no great variation with cell size, whereas the effect of the density on these couple of values can not be evaluated properly due to the low density range of the foams fabricated.

Table III presents the mechanical data derived from the stress-strain curves obtained. First, compressive elastic modulus $\mathrm{E}$ is obtained, from the linear fit obtained in the first part of the curve. Nextly, yield stress $\sigma_{y}$ is showed, calculated directly from the experimental data. Next, the densification strain $\varepsilon_{D}$, obtained directly from the intersection point $\mathrm{B}$, is presented in the Table III. Finally, as a first approximation, the density of energy absorbed up to $50 \%$ of strain is showed, calculated from direct integration

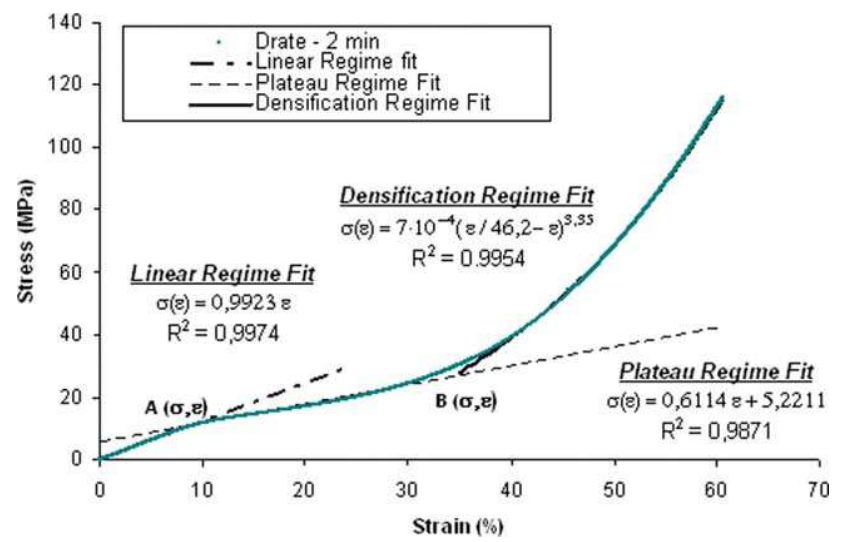

Figure 8 Fitting of the stress-strain curves according to Gibson's modified model. [Color figure can be viewed in the online issue, which is available at www.interscience. wiley.com.] 
TABLE II

Fitting Parameters Obtained in all the Samples

\begin{tabular}{cccccc}
\hline $\begin{array}{c}\text { Depressurization } \\
\text { time }(\mathrm{min})\end{array}$ & $\begin{array}{c}\text { Cell } \\
\text { size }(\mu \mathrm{m})\end{array}$ & $\begin{array}{c}\text { Foam } \\
\text { density } \\
\left(\mathrm{g} / \mathrm{cm}^{3}\right)\end{array}$ & $E_{T}$ & $D$ & $m$ \\
\hline 1 & 1 & 1.01 & $0.98 \pm 0.01$ & $45.23 \pm 2.21$ & $1.32 \pm 0.14$ \\
2 & 3 & 0.93 & $0.81 \pm 0.02$ & $32.54 \pm 1.32$ & $3.43 \pm 0.13$ \\
4 & 5 & 0.97 & $0.75 \pm 0.02$ & $34.12 \pm 0.98$ & $3.41 \pm 0.13$ \\
6 & 7 & 0.88 & $0.59 \pm 0.01$ & $32.56 \pm 1.25$ & $3.12 \pm 0.14$ \\
8 & 10 & 0.89 & $0.50 \pm 0.02$ & $31.98 \pm 1.08$ & $3.67 \pm 0.12$ \\
10 & 30 & 0.87 & $0.35 \pm 0.02$ & $34.54 \pm 1.03$ & $3.73 \pm 0.12$ \\
15 & 50 & 0.90 & $0.36 \pm 0.01$ & $33.23 \pm 1.32$ & $3.89 \pm 0.13$ \\
30 & 200 & 0.85 & $0.24 \pm 0.03$ & $32.21 \pm 1.21$ & $3.93 \pm 0.13$ \\
\hline
\end{tabular}

under the curve from initial deformation up to $50 \%$, using the next equation.

$$
W_{50}=\int_{\varepsilon_{i}}^{\varepsilon_{f}} \sigma(\varepsilon) d \varepsilon
$$

As it can be derived from previous data, elastic compressive modulus decreases with cell size. Values of $E$ are between $1.24 \mathrm{GPa}$, for samples with $1 \mu \mathrm{m}$ of cell size, to $0.40 \mathrm{GPa}$ in samples with $200 \mu \mathrm{m}$ of cell size. Comparing these results with elastic compressive modulus of solid material $\left(E_{s}=3.46 \mathrm{GPa}\right.$, measured in the same conditions), foaming results in a decrease of the elastic compressive modulus.

Concerning the theoretical approximations, the elastic compressive modulus $E$ has been predicted in several ways. First, a microstructural approximation has been given by Gibson and Ashby. In this assumption, $E$ can be predicted by the following equation in the sum of three contributions ${ }^{38}$ :

$$
\begin{aligned}
\frac{E}{E_{s}} & =\frac{E_{c}}{E_{s}}+\frac{E_{f}}{E_{s}}+\frac{E_{g}}{E_{s}} \\
& =\phi^{2}\left(\frac{\rho_{f}}{\rho_{s}}\right)^{2}+(1-\phi)\left(\frac{\rho_{f}}{\rho_{s}}\right)+\frac{P_{0}(1-2 v)}{E_{s}\left(1-\rho_{f} / \rho_{s}\right)}
\end{aligned}
$$

where $\varphi$ is the volume fraction of the solid contained in the cell edges, $v$ is the poisson's ratio, assumed usu- ally as 0.33 and $P_{0}$ is the initial pressure of the cell fluid in the closed cell. The rest of the parameters are defined previously. In eq. (8), first term corresponds to the contribution of the bending of cell edges to elastic modulus, the second term is the contribution of the stretching of the wall membranes and finally the third term is the contribution of gas compression. Considering $P_{0}$ as atmospheric pressure $(0.1 \mathrm{MPa})$, the third term of eq. (6) can be neglected, and the compressive elastic modulus of the foam can be expressed as:

$$
\frac{E}{E_{s}}=\frac{E_{c}}{E_{s}}+\frac{E_{f}}{E_{s}}=\phi^{2}\left(\frac{\rho_{f}}{\rho_{s}}\right)^{2}+(1-\phi)\left(\frac{\rho_{f}}{\rho_{s}}\right)
$$

which is the Gibson-Ashby model for describing the closed cell foam materials. However, this equation is focused in low density materials, in which the $\varphi$ parameter can be determined easily from the SEM observations. In our case, for high density materials in the microcellular range, a precise determination of $\varphi$ is not possible. On the other hand, the dependence of the elastic compressive modulus with cell size, has been analyzed by several authors, ${ }^{42}$ although there is not a general expression explaining the dependence of cell size to elastic compressive modulus. Zhiqiang and Scanlon ${ }^{42}$ proposed an equation which integrated the macro and microscopic scaling of the cellular solid:

TABLE III

Mechanical Parameters Obtained from the Stress-Strain Curves

\begin{tabular}{ccccccc}
\hline $\begin{array}{c}\text { Depressurization } \\
\text { time }(\mathrm{min})\end{array}$ & $\begin{array}{c}\text { Cell } \\
\text { size }(\mu \mathrm{m})\end{array}$ & $\begin{array}{c}\text { Foam } \\
\text { density } \\
\left(\mathrm{g} / \mathrm{cm}^{3}\right)\end{array}$ & $\varepsilon_{D}(\%)$ & $E(\mathrm{GPa})$ & $\begin{array}{c}\text { Yield } \\
\text { stress } \\
(\mathrm{MPa})\end{array}$ & $\begin{array}{c}W_{50} \\
\left(\mathrm{MJ} / \mathrm{m}^{3}\right)\end{array}$ \\
\hline 1 & 1 & 1.01 & 38.4 & 1.24 & 17.71 & 1097 \\
2 & 3 & 0.93 & 46 & 1.22 & 12.07 & 1132 \\
4 & 5 & 0.97 & 47 & 0.85 & 11.35 & 1237 \\
6 & 7 & 0.88 & 49 & 0.76 & 10.12 & 913 \\
8 & 10 & 0.89 & 49.1 & 0.68 & 8.67 & 763 \\
10 & 30 & 0.87 & 52.5 & 0.60 & 9.02 & 564 \\
15 & 50 & 0.90 & 53.3 & 0.51 & 8.72 & 527 \\
30 & 200 & 0.85 & 54.4 & 0.40 & 6.31 & 477 \\
Bulk material & N/A & N/A & N/A & 3.46 & N/A & 814 \\
\hline
\end{tabular}




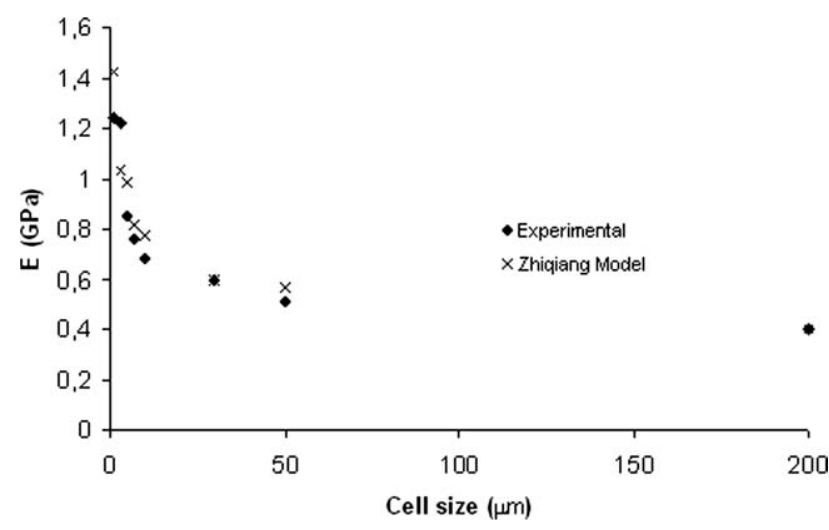

Figure 9 Theoretical correlation of elastic compressive modulus. (Correlation factor $D=2.5$ ).

$$
\frac{E}{E_{s}} \propto\left(\frac{R}{r}\right)^{D-2}\left(\frac{\rho_{f}}{\rho_{s}}\right)^{1 /(3-D)}
$$

In this expression, $R$ is a parameter defined as macroscopical length of the sample (the length of the sample that is tested), $r$ is the average cell size and $D$ is a fitting parameter which depends on the material. Thus, the ratio $R / r$ can be considered the number of cells compressed during the test. The theoretical correlation of this approximation to experimental values is presented in Figure 9.

As it is shown in Figure 9, correlation between experimental results and theoretical prediction shows a good agreement. Only at low cell sizes (below 3 $\mu \mathrm{m})$, the predicted values are higher than experimental results. This indicates the range of validity of the model, and it can be said that, considering this range, expression 10 can be employed to predict the elastic compressive modulus of the microcellular material as a function of cell size.

The other key parameter that must be considered is the density of energy absorbed. From the data in Table III, it reaches is maximum at cell sizes of 5 $\mu \mathrm{m}$, showing a value of $1237 \mathrm{MJ} / \mathrm{m}^{3}$. It is important to remark that energy absorbed for the solid material is $814 \mathrm{MJ} / \mathrm{m}^{3}$, calculated from the experimental mechanical data obtained in the same conditions, which means that microcellular foaming at low cell sizes improve the capability of energy absorption of the material, reducing at the same time the density. Although energy absorption is one of the most important properties of the cellular solids, there is a lack of expressions correlating the microstructural parameters, such cell size, and density of energy absorbed. In this line, only phenomenological expressions have been proposed, ${ }^{38}$ using the foam density as main parameter to predict the density of energy absorbed in the material. It is important to remark that this investigation is only focused in compression at low strain rates, (cuasi-static range), and for applications in which impact resistance is needed (for example, packaging, passive safety, etc...), compression tests at higher velocities must be performed. Following this line, several authors have investigated the strain rate sensitivity of the main mechanical parameters, ${ }^{43,44}$ showing that for higher strain rates (above $100 \mathrm{~s}^{-1}$ ), the results are not comparable. However, mechanical parameters are strain rate independent in a wide range of strain rates (from $10 \mathrm{~s}^{-1}$ to $100 \mathrm{~s}^{-1}$ ).

A more precise determination of the energy dissipation of a cellular material is given by Viot, ${ }^{45}$ in which polypropylene and polystyrene foams are designed to optimize passive safety structures in helmets. Following this line, to determine which is the cellular material most effective for an specific energy absorption application, it is necessary to calculate the relation between density of energy absorbed and nominal stress. Figure 10 presents the results obtained for the microcellular PMMA samples produced.
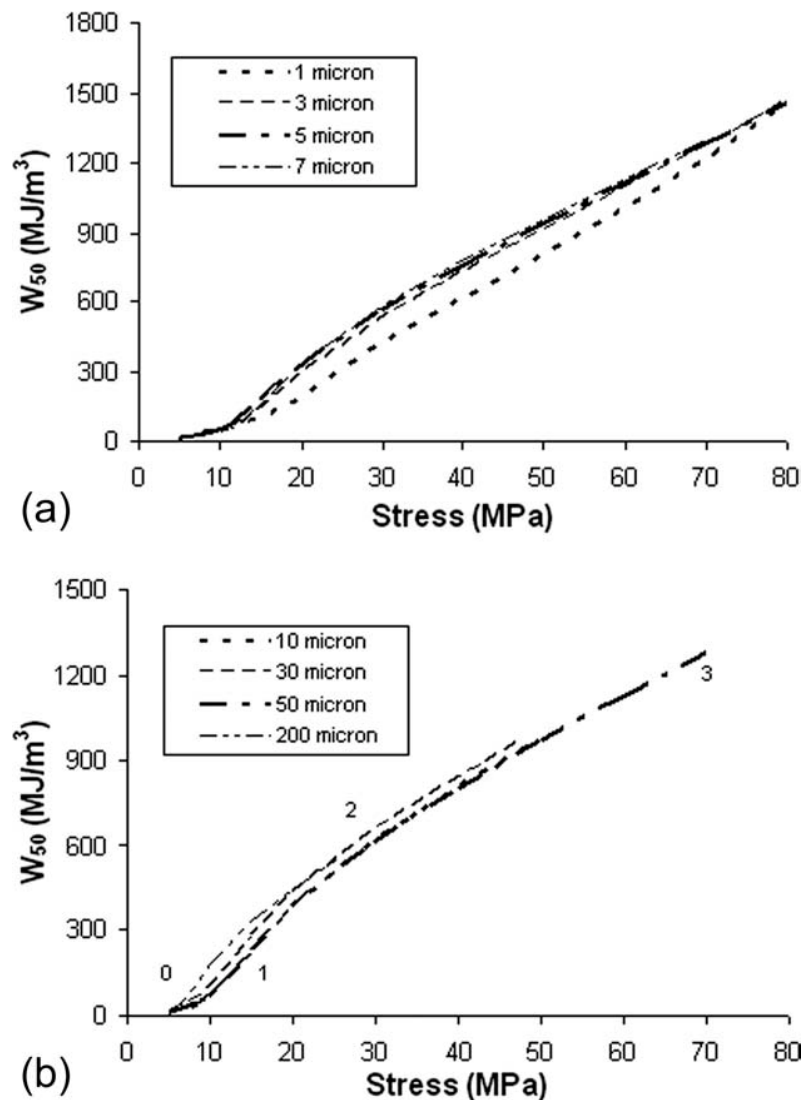

Figure 10 (a) Energy versus stress results of static compression of microcellular reinforced PMMA foams with cell sizes of $1 \infty \mathrm{m}, 3 \infty \mathrm{m}, 5 \infty \mathrm{m}$, and $7 \infty \mathrm{m}$. (b) Energy versus stress results of static compression of microcellular reinforced PMMA foams with cell sizes of $10 \propto \mathrm{m}, 30 \infty$ $\mathrm{m}, 50 \propto \mathrm{m}$, and $200 \infty \mathrm{m}$. 

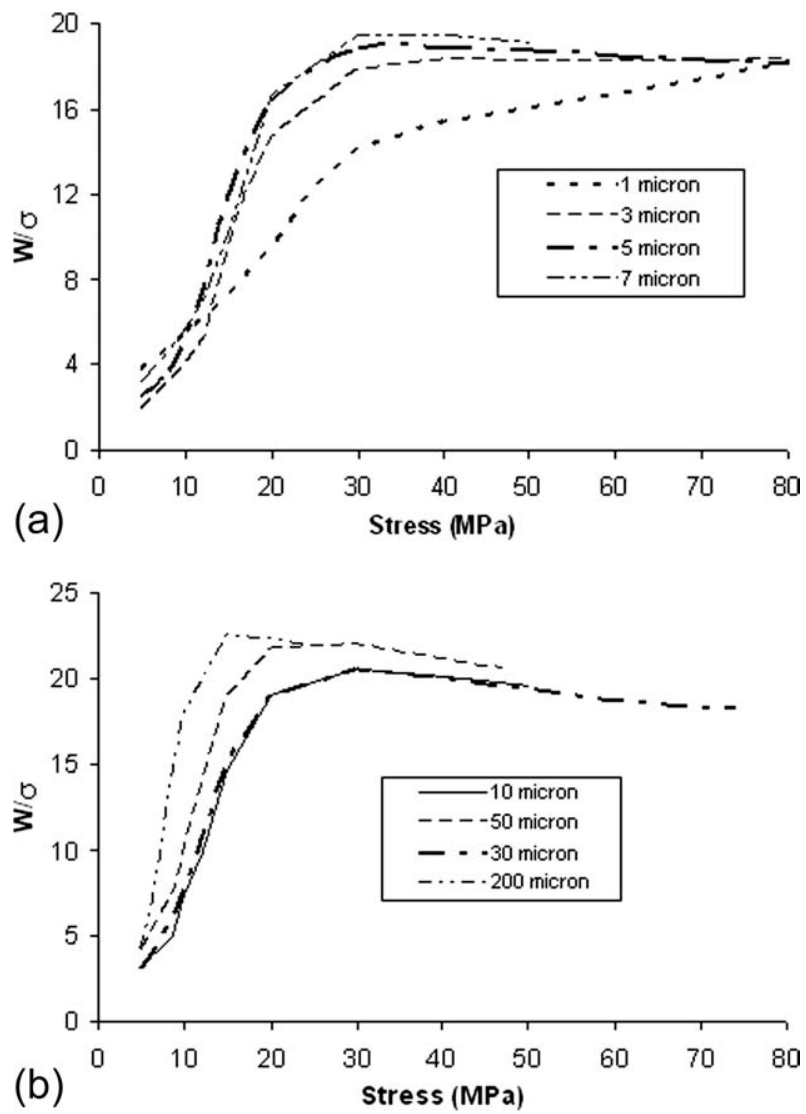

Figure 11 (a) Evolution of $W / \sigma$ ratio versus stress in the microcellular reinforced PMMA foams with cell sizes of 1 $\mu \mathrm{m}, 3 \mu \mathrm{m}, 5 \mu \mathrm{m}$, and $7 \mu \mathrm{m}$. (b) Evolution of $\mathrm{W} / \sigma$ ratio versus stress in the microcellular reinforced PMMA foams with cell sizes of $10 \mu \mathrm{m}, 30 \mu \mathrm{m}, 50 \mu \mathrm{m}$, and $200 \mu \mathrm{m}$.

In the experimental data presented in Figure 10, the first zone of the curve, between initial point 0 and point 1 , corresponds to the density of energy absorbed in the elastic phase, $W$. In this region, $W$ is low and the stress reaches the yield stress of the material $\sigma_{y}$. Next zone, between points 1 and 2, is related to the energy absorbed during the plateau stress, the phase of more interest for the energy absorption study. In this zone, it is possible to determine the optimum point 2 , usually characterized by the density of energy absorbed, the stress $\sigma$ and the density of material, in which the ratio $W / \sigma$ is maximum. Finally, the last zone of the curve is situated between points 2 and 3, and the absorbed energy continues to increase but at a lower $W / \sigma$ ratio. Figure 11 shows the results of the evolution of the ratio $W / \sigma$ versus stress.

As it can be seen in Figure 11(a), the $W / \sigma$ ratio increases continuously in microcellular foams with cell sizes of $1 \mu \mathrm{m}, 3 \mu \mathrm{m}$, and $5 \mu \mathrm{m}$, and a maximum is not observed. In these materials, plateau regime is not well defined, as it is showed in Table II, where the values of the tangent modulus $E_{T}$ are $0.98,0.81$, and 0.75 , respectively. On the contrary, a maximum in the $W / \sigma$ ratio is presented in microcellular PMMA foams with higher cell sizes, $7 \mu \mathrm{m}$ [Fig. 11(a)] and $10 \mu \mathrm{m}, 30 \mu \mathrm{m}, 50 \mu \mathrm{m}$, and $200 \mu \mathrm{m}$ [Fig. 11(b)]. Values of $W / \sigma$ vary from 18.84 , in the sample with $7 \mu \mathrm{m}$ of cell size to 22.47 for the sample with higher cell size $(200 \mu \mathrm{m})$. In these samples, values of tangent modules $E_{T}$ are lower, from 0.59 to 0.24 and the plateau regime is more evident.

\section{Neat PMMA resin}

To investigate the effect of the core/shell particles in the compression properties of the microcellular PMMA, a collection of compression tests, under the same experimental conditions, were carried out in neat PMMA microcellular samples. A summary of the main mechanical results derived from the experiments (densification strain $\varepsilon_{D}$, yield stress $\sigma_{y}$, elasticity modulus $E$ and density of energy absorbed $W_{50}$ ) is presented in Table IV.

Results in previous table show that reinforced core/shell PMMA foams presents great values of elasticity modulus $E$ than neat PMMA foams, for all the samples fabricated. In addition, there is a slightly increase in the values of yield stress $\sigma_{y}$ obtained for the core/shell PMMA foams. On the contrary hand, the rest of the mechanical parameters analyzed (the densification strain $\varepsilon_{\mathrm{d}}$ and the density of energy absorbed $W_{50}$ ) present similar values for both materials. In this case, cellular structure and foam density

TABLE IV

Comparison Between Mechanical Data of Neat PMMA Foams and Reinforced PMMA Foams

\begin{tabular}{|c|c|c|c|c|c|c|c|c|}
\hline \multirow[b]{2}{*}{$D_{\text {rate }}(\min )$} & \multicolumn{4}{|c|}{ Neat PMMA } & \multicolumn{4}{|c|}{ Reinforced core/shell PMMA } \\
\hline & $\varepsilon_{D}(\%)$ & $E(\mathrm{GPa})$ & $\sigma_{y}(\mathrm{MPa})$ & $W_{50}\left(\mathrm{MJ} / \mathrm{m}^{3}\right)$ & $\varepsilon_{D}(\%)$ & $E(\mathrm{GPa})$ & $\sigma_{y}(\mathrm{MPa})$ & $W_{50}\left(\mathrm{MJ} / \mathrm{m}^{3}\right)$ \\
\hline 1 & 36.7 & 1.08 & 16.11 & 974 & 38.4 & 1.24 & 17.71 & 1097 \\
\hline 2 & 49 & 1.02 & 11.17 & 1245 & 46 & 1.22 & 12.07 & 1132 \\
\hline 4 & 42 & 0.74 & 9.25 & 1134 & 47 & 0.85 & 11.35 & 1237 \\
\hline 6 & 51 & 0.67 & 9.36 & 934 & 49 & 0.76 & 10.12 & 913 \\
\hline 8 & 52.3 & 0.61 & 7.45 & 712 & 49.1 & 0.68 & 8.67 & 763 \\
\hline 10 & 52.7 & 0.52 & 7.98 & 678 & 52.5 & 0.60 & 9.02 & 564 \\
\hline 15 & 55.9 & 0.43 & 7.35 & 513 & 53.3 & 0.51 & 8.72 & 527 \\
\hline 30 & 51.1 & 0.31 & 6.45 & 409 & 54.4 & 0.40 & 6.31 & 477 \\
\hline
\end{tabular}


seems to be the key parameters which control the mechanical behavior, whereas reinforcement effects are appreciable in cases in which the matrix polymer is the key parameter which governs the mechanical behavior. This result is in accordance with the work of Lalande et al., ${ }^{30}$ in which the effect of the reinforcement in solid PMMA is observed during tensile tests. In our work, we present a similar effect considering compression properties on microcellular foamed materials.

\section{CONCLUSIONS}

A collection of PMMA microcellular foams was fabricated in supercritical carbon dioxide using a batch process. Controlled cell size was achieved by varying depressurization time, from $60 \mathrm{~s}$ to $30 \mathrm{~min}$, leading to cell sizes from $1 \mu \mathrm{m}$ to $200 \mu \mathrm{m}$ and minimizing at the same time the variation of density $(1.0 \mathrm{~g} /$ $\mathrm{cm}^{3}-0.8 \mathrm{~g} / \mathrm{cm}^{3}$ ). Compression mechanical tests were carried out at low strain $(0.5 \mathrm{~mm} / \mathrm{min})$ in all the samples, showing the clear influence of cell size on the main mechanical parameters. A decrease of elastic compressive modulus and yield stress was observed respect to solid material, and a maximum of absorbed energy up to $50 \%$ strain was found for microcellular samples with $5 \mu \mathrm{m}$ of cell size. In addition, the calculation of the energy absorbed was carried out, and the point of maximum efficiency was obtained for each cell size. The influence of rubber core/shell particles as a reinforcement in the PMMA matrix has been analyzed, comparing the foaming behavior and mechanical properties of neat PMMA foams to reinforced core/shell PMMA foams. Results obtained indicate that reinforcement does not affect greatly to the foaming behavior, but compression properties, such as elasticity modulus $E$ and yield stress $\sigma_{y}$ are increased due to the presence of the reinforce particles.

\section{References}

1. Cooper, A. I. J Mater Chem 2000, 10, 207.

2. Jessop, P. G.; Leitner, W. Chemical Synthesis using Supercritical Fluids; Wiley. VCH: Weinheim, 1999.

3. Baiker, A. Chem Rev 1999, 99, 453.

4. Martini, J. E.; Waldman, F. A.; Suh, N. P. U.S. Pat. 4,473,665 (1984).

5. Martini, J. E.; Waldman, F. A.; Suh, N. P. SPE Tech Pap 1982, 28,674 .

6. Reverchon, E.; Cardea, S. J Supercrit Fluids 2007, 40, 317.
7. Yoon, J. D.; Cha, S. W. Polym Test 2001, 20, 287.

8. Arora, K. A.; Lesser, A. J.; Mccarthy, T. J. Macromolecules 1998, 31, 2252.

9. Mascia, L.; Del Re, G.; Ponti, P. P.; Bologna, S.; Di Giacomo, G. Adv Polym Technol 2006, 25, 225.

10. Jacobs, L. J. M.; Danen, K. C. H.; Kemmere, M. F.; Keurentjes, J. T. F. Polymer 2007, 48, 3771.

11. Uosaki, Y.; Morokami, T.; Moriyoshi, T. High Pressure Res 2001, 20, 467.

12. He, Y.; Xin, C.; Li, Q.; Wang, S. J Beijing Univ Chem Technol 2002, 36, 121.

13. Krause, B.; Sijbesma, H. J. P.; Munuklu, P.; Van Der Vegt, F. A.; Wessling, M. Macromolecules 2001, 34, 8792.

14. Sumarno, A. R.; Bernardus, G. S.; Ismail, A. S.; Putu Teta, P. A. Proceeding of the Eight meeting on Supercritical Fluids (Chemical Reactivity and material processing in supercritical fluids); Bordeaux, 2002, pp 144-152.

15. Arora, K. A.; Lesser, A. J.; McCarthy, T. J. Polym Eng Sci 1998, 38, 7610.

16. Doroudian'i, S.; Park, C. B.; Kortschot, M. Polym Eng Sci 1998, 38, 1205.

17. Doroudian'i, S.; Park, C. B.; Kortschot, M. Polym Eng Sci 1996, 36, 1437.

18. Sun, H.; Sur, G. S.; Mark, J. E. Eur Polym J 2002, 38, 2373.

19. Sun, H.; Mark, J. E. J Appl Polym Sci 2002, 86, 1692.

20. Kwon, Y. K.; Bae, H. K. Korean J Chem Eng 2007, 24, 127.

21. Jo, C.; Nagui, H. E. Cell Polym 2005, 24, 177.

22. Matuana, L. M. Bioresour Technol 2008, 99, 3643.

23. Rindfleisch, F.; Dinoia, T. P.; Mchugh, M. A. J Phys Chem 1996, 100, 15581.

24. Ito, Y.; Yamashita, M.; Okamoto, M. Macromol Mater Eng 2006, 291, 773.

25. Jo, C.; Naguib, H. E. J Physics: Conf Ser 2007, 61, 861.

26. Zhai, W.; Yu, J.; Wu, L.; Ma, W.; He, J. Polymer 2006, 47, 7580.

27. Yokoyama, H.; Sugiyama, K. Macromolecules 2005, 38, 10516.

28. Shieh, Y. T.; Liu, K. H. J Polym Res 2002, 9, 107.

29. Otsuka, T.; Taki, K.; Ohshima, M. Macromol Mater Eng 2008, 293, 78 .

30. Lalande, L.; Plummer, C. J. G.; Anders, J.; Manson, E.; Gerard, P. Polymer 2006, 47, 2217.

31. Tang, M.; Du, T. B.; Chen, Y. P. J Supercrit Fluids 2004, 28, 207.

32. Condo, P. D.; Sanchez, I. C.; Panayiotou, C. G.; Johnston, K. P. Macromolecules 1992, 25, 6730.

33. Zhang, Z.; Handa, P. J Polym Science: Part B 1998, 36, 977.

34. Handa, P.; Zhang, Z. J Polym Science: Part B 2000, 38, 241.

35. Kumar, V.; Suh, N. P. Polym Eng Sci 1990, 30, 1323.

36. Nawaby, A. V.; Handa, Y. P.; Liao, X.; Yoshitaka, Y.; Tomohiro, M. Polym Int 2007, 56, 67.

37. Goel, S. K.; Beckman, E. J Polym Eng Sci 1994, 34, 1137.

38. Gibson, L. J.; Ashby, M. F. Cellular solids. Structure and properties; Cambridge University Press: Cambridge, UK, 1997.

39. Rusch, K. C. J Appl Polym Sci 1969, 13, 2297.

40. Rusch, K. C. J Appl Polym Sci 1969, 14, 1133.

41. Rusch, K. C. J Appl Polym Sci 1970, 14, 1263.

42. Zhiqiang, L.; Scanlon, M. G. J Mater Sci Lett 2003, 22, 547.

43. Wang, B.; Peng, Z.; Zhang, Y.; Zhang, Y. J Appl Polym Sci 2007, 105, 3834.

44. Subhash, G.; Liu, Q.; Gao, X. Int J Impact Eng 2006, 32, 1113.

45. Viot, P. Int J Crash Worthiness 2007, 12, 3, 299. 